Article - Agriculture, Agribusiness and Biotechnology

\title{
Dormancy of Floral Buds of Rabbiteye Blueberry in a Mild Winter Climate
}

\author{
Carolina Schuchovski ${ }^{1}$ \\ https://orcid.org/0000-0002-6328-8991 \\ Luiz Antonio Biasi ${ }^{2 \star}$ \\ https://orcid.org/0000-0002-3479-8925
}

${ }^{1}$ Federal University of Paraná, Graduate Program in Agronomy - Plant Production, Curitiba, Paraná, Brazil; ${ }^{2}$ Federal University of Paraná, Department of Crop Science and Plant Pathology, Curitiba, Paraná, Brazil.

Editor-in-Chief: Paulo Vitor Farago

Associate Editor: Adriel Ferreira da Fonseca

Received: 2019.12.14; Accepted: 2020.09.10.

*Correspondence: biasi@ufpr.br; Tel.: +55-41-3350-5682 (L.A.B).

\section{HIGHLIGHTS}

- This work studies the dormancy dynamics of blueberries growing in mild winter regions.

- The four rabbiteye blueberry cultivars meet the chilling requirements in the study.

- The floral buds of 'Delite' are more precocious than the other cultivars.

- Insights on how temperate fruit species could behave in warming climate scenarios.

\begin{abstract}
Blueberry is an important fruit crop, with many health benefits. Despite its importance, much remains to be studied concerning the dormancy dynamics in rabbiteye cultivars growing in a mild winter climate. In this research, the dormancy in blueberry, rabbiteye cultivars 'Bluegem', 'Climax', 'Delite', and 'Powderblue', was studied in a mild winter region. The single-node cuttings biological test and the evaluation of the hydric status were performed in dormant winter reproductive buds. These experiments were performed during fall and winter in one year (2016). Moreover, chilling hours under or equal to $7.2 \stackrel{\circ}{\circ}$ were measured, and chill units were calculated according to Utah Model [1], Modified Utah Model [2], and Blueberry Model [3]. In conclusion, the four cultivars showed a similar pattern, revealing a dormant state in the initial sampling dates and a released dormancy in the final treatments, showing the decrease of dormancy in June and July. However, Delite was earlier than the other cultivars. Bluegem and Delite required 134.0 chilling hours, 127.0 chill units (Utah Model), 198.5 chill units (Modified Utah Model), and 971.5 chill units (Blueberry Model) for $50 \%$ of their green tip buds reach the opened bud stage. Climax required 44.0, -11.0, 56.5, and 440.5, respectively. And Powderblue required 44.0, 5.5, 77.0, and 725.0 respectively. This study can bring some insights into crop management and production of this important fruit crop, especially in a global climatechanging scenario, related to flowering and dormancy control, as well as helping to select suitable cultivars to a region, concerning chilling requirements.
\end{abstract}

Keywords: blueberry; bud; budbreak; chilling; climate change; dormancy; Ericaceae; Vaccinium. 


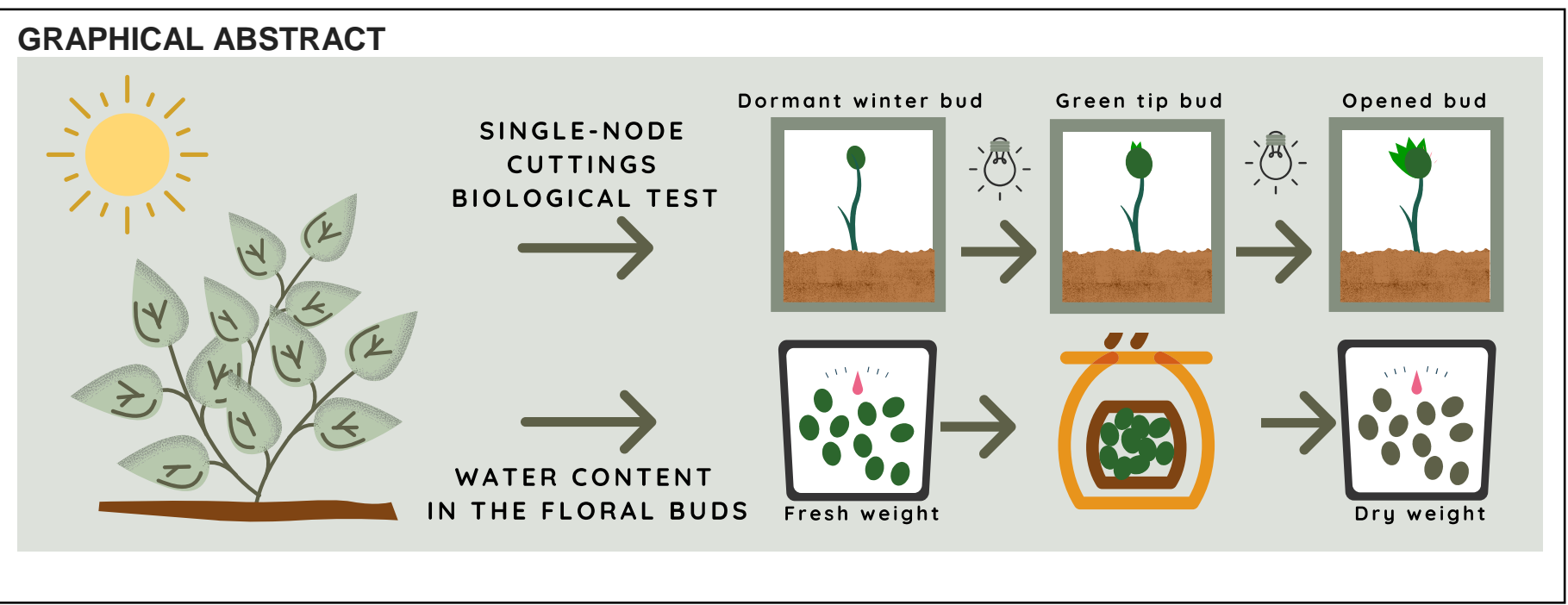

\section{INTRODUCTION}

The bud dormancy phenomenon has been studied in many perennial plants [4]. The process of dormancy was defined by Lang [5] as a "temporary suspension of visible growth of any plant structure containing a meristem". It was described and classified by the author as ecodormancy, paradormancy, and endodormancy. Ecodormancy is regulated by environmental factors; for example, buds in extreme environmental conditions, such as low temperatures or drought periods, can pause growth and can resume growth after all the essential factors required for it are adequate. Paradormancy is a correlative inhibition, caused by physiological circumstances outside the bud itself, such as apical dominance. Finally, endodormancy is regulated by physiological factors inside the affected bud [5], and it can occur in most temperate climates in early autumn. Endodormant buds have a delay and reduced growth rate compared to non-dormant buds when placed in growth-adequate conditions. This endodormancy could be triggered by short day length or short periods of cold temperatures, and it needs an extended cold or drought treatment to be broken [4]. Once the endodormant bud is not released, it cannot grow. In temperate climates, the chilling amount to release the bud endodormancy can be easily met. However, in tropical or subtropical areas, temperate species can face a problem in budbreak and flowering if temperatures are not cold enough [6].

Although many factors related to dormancy have been studied, some of them remain still unsolved [7]. One of the approaches used is the single-node cuttings biological test [8], used to determine the depth of the bud dormancy [9]. It has been performed in several species such as apricot [10], plum [11,12], peach [6,11,13,14], apple [15-17], pear [15,16,18], sweet cherry [19], kiwi [20], and grape [20].

Another test is to evaluate the hydric status of the buds, which can be linked to the dormancy mechanisms [21]. Some other methods that can be used to estimate the completion of the dormancy period are based on calculating the chilling hours (number of hours below $7.2{ }^{\circ} \mathrm{C}$ ) or the chill units and comparing them to each cultivar chilling requirements. Since the chilling hours method does not consider temperatures above $7.2^{\circ} \mathrm{C}$, that could influence dormancy, some other methods were developed, using chill units. These methods can estimate a broader temperature range, with a positive or negative chill-unit contribution [2] converting temperatures into chilling units necessary for dormancy break. One of them, the Utah Chill Unit Model [1], consists of a mathematical model that relates the temperatures to effective chill units. Considering that in mild winter climate regions, the lower fall and winter temperatures can be interrupted by higher temperatures, the original Utah Model may not work all the years satisfactorily, resulting in a negative accumulated chilling. For this reason, some other models have been developed, such as the Modified Utah Chill Unit Model [2]. In this model, there is a restriction on the accumulation of the high temperatures in between lower temperatures during the fall and winter [22]. This modification represents a more suitable model for mild-winter conditions, where chilling temperatures can be interrupted by higher temperatures [2]. In another approach, specifically in a rabbiteye blueberry cultivar, Spiers [3] used a chill unit model proposed by Biggs [23] that takes into consideration that the chilling requirements of rabbiteye blueberries are partially accomplished by higher temperatures [24].

Blueberry is a woody perennial species in the family Ericaceae and genus Vaccinium [25]. There are several species of blueberries in the genus Vaccinium, and cultivars are separated into three groups, highbush, lowbush, and rabbiteye, according to their chilling requirement and winter cold hardiness. 
Rabbiteye cultivars are the least demanding in chilling hours for normal floral development, and their floral buds do not tolerate temperatures much below freezing [24]. Even using low chilling demanding cultivars, growing temperate species under subtropical or tropical climate can represent a challenge to overcome, primarily related to chilling requirements and transposing the buds dormancy [7]. The right amount of chilling accumulation is essential for floral bud formation. If these requirements are not met, budbreak and fruit production can be highly affected [26]. Therefore, understanding the complex process of dormancy in temperate species has a vital role in studying their physiological behavior. It can also help develop more assertive agronomical traits, such as, in low chill cultivars (mostly evergreen), the combination of pruning with drought, for example, to help induce dormancy.

Even though some aspects related to the dormancy in some blueberry cultivars have been described [3,27-29], some aspects need further understanding, especially concerning growing Rabbiteye cultivars in mild winter regions. To address this gap, the objective of this work was to study the seasonal dynamics of reproductive buds in blueberry, rabbiteye cultivars, under subtropical climatic conditions, in one year (2016). For this research, the single-node cuttings biological test and the estimation of the relative water content and the water content in the floral buds were performed in four different cultivars 'Bluegem', 'Climax', 'Delite' and 'Powderblue', along with the estimation of chilling hours, and chilling units using three different methods and comparing the chilling accumulation to the dormancy behavior of the floral buds.

\section{MATERIAL AND METHODS}

\section{Plant material}

The study was conducted during the Southern Hemisphere fall and winter (from April to August 2016). Four rabbiteye blueberry cultivars, Vaccinium virgatum Ait., were tested: 'Bluegem', 'Climax', 'Delite' and 'Powderblue'. Plant material was collected from an orchard at Canguiri Experimental Station/UFPR in Pinhais/PR/Brazil (920 m above sea level; latitude 25 $23^{\circ} \mathrm{S}$; and longitude $49^{\circ} 07^{\prime} \mathrm{W}$ ) and experiments were conducted at the Micropropagation Laboratory, UFPR.

\section{Climatic characterization}

The climate in the region is $\mathrm{Cfb}$, according to Köppen, humid subtropical zone, oceanic climate without a dry season and with temperate summer, with summer temperatures below $22{ }^{\circ} \mathrm{C}$ and winter temperatures ranging between $18{ }^{\circ} \mathrm{C}$ and $-3^{\circ} \mathrm{C}$ [30]. In this year studied (2016), according to data from Simepar at Pinhais Meteorological Station, the monthly average temperatures in April, May, June and July were 20.3, 14.5, 11.2, and $13.7^{\circ} \mathrm{C}$, respectively (Figure 1 ). The average maximum temperatures were $26.3,18.8,16.4$, and 19.7 ${ }^{\circ} \mathrm{C}$, respectively and the average minimum temperatures were $16.3,11.6,7.5$, and $8.9{ }^{\circ} \mathrm{C}$, respectively. The beginning of April showed high temperatures, but at the end of month temperatures dropped down. May showed higher precipitation compared to other years. And June and July had many consecutive days of low temperatures [31]. The daily temperatures are shown in Figure 2. Negative temperatures were observed only on June $12\left(-1.4^{\circ} \mathrm{C}\right)$ and June $13\left(-0.2^{\circ} \mathrm{C}\right)$. 


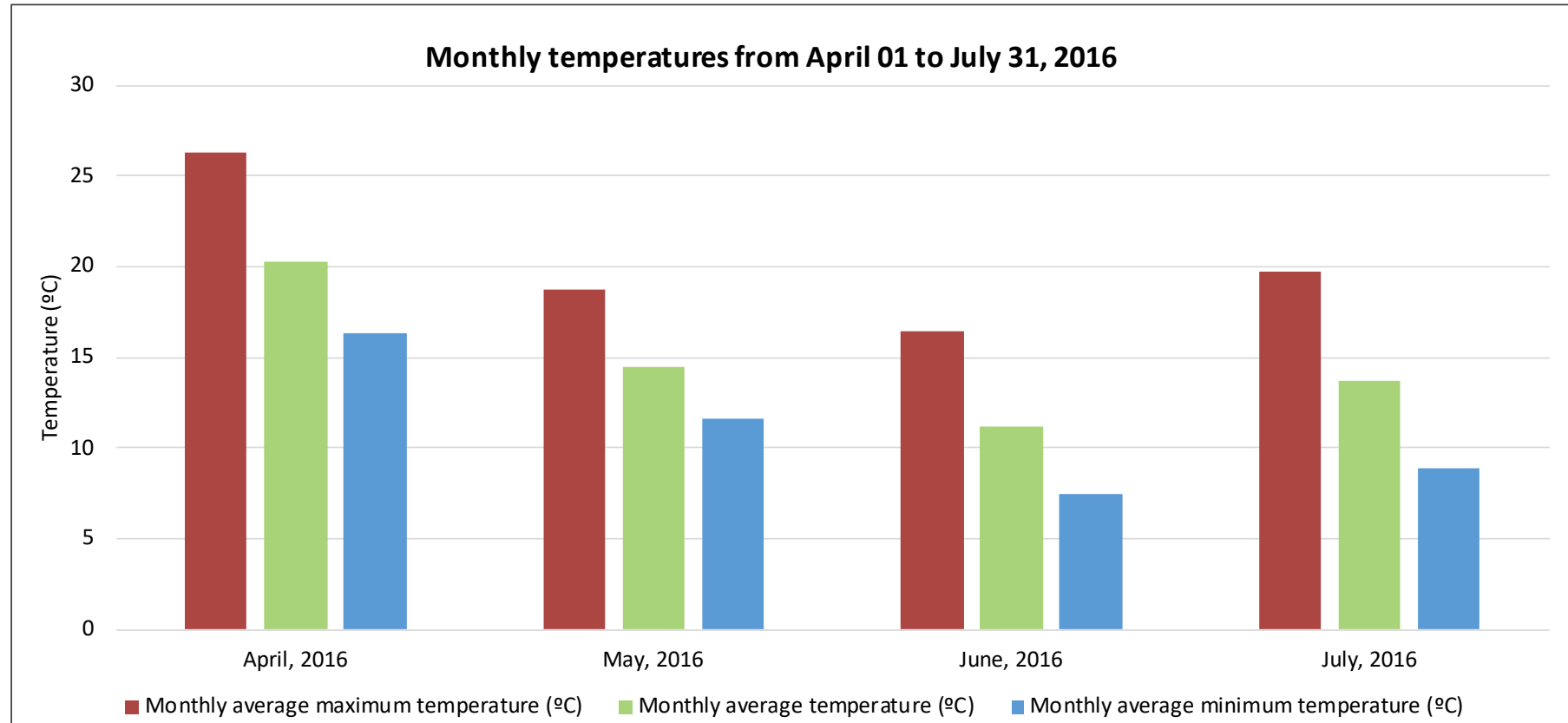

Figure 1. Monthly temperatures from April to July 2016, in Pinhais/PR/Brazil. Data from Simepar-Pinhais Meteorological Station.

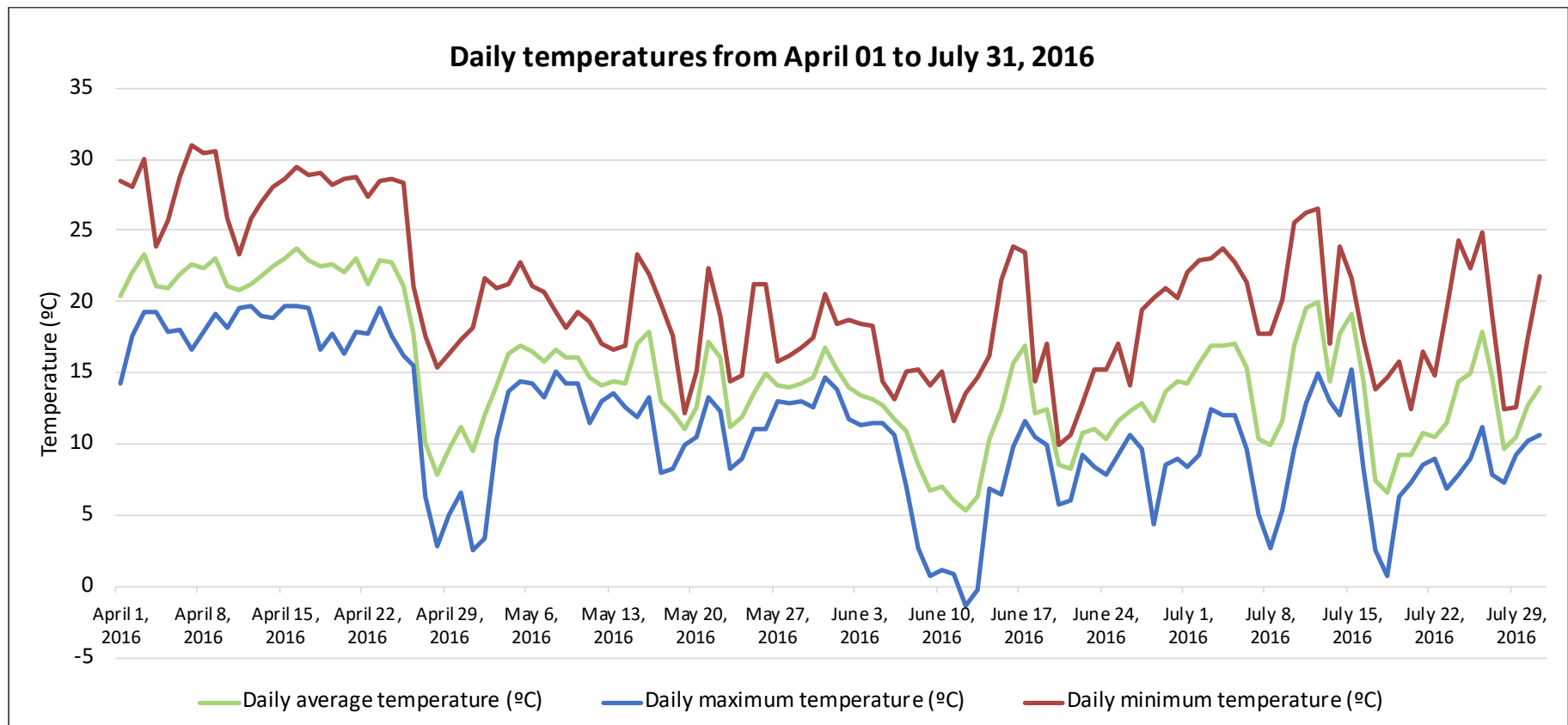

Figure 2. Daily temperatures from April to July 2016, in Pinhais/PR/Brazil. Data from Simepar-Pinhais Meteorological Station.

\section{Single-node cuttings biological test}

The dynamics of dormancy was studied using the single-node cuttings biological test [8]. Shoots containing floral buds were collected every two weeks, from April 25 to August 1, 2016 (eight sampling dates), and were treated with an immersion in fungicide solution for 5 minutes (Cercobin $® 0.2 \%$ ). The most apical region of the stem was discarded, and 40 cuttings, $5 \mathrm{~cm}$ long, were prepared for each cultivar, in each date of collecting, totalizing 160 cuttings per collecting date and 1280 cuttings in the total. Each cutting maintained only one floral bud (the most apical one) and had all the leaves and the rest of the buds removed (Figure 3). 

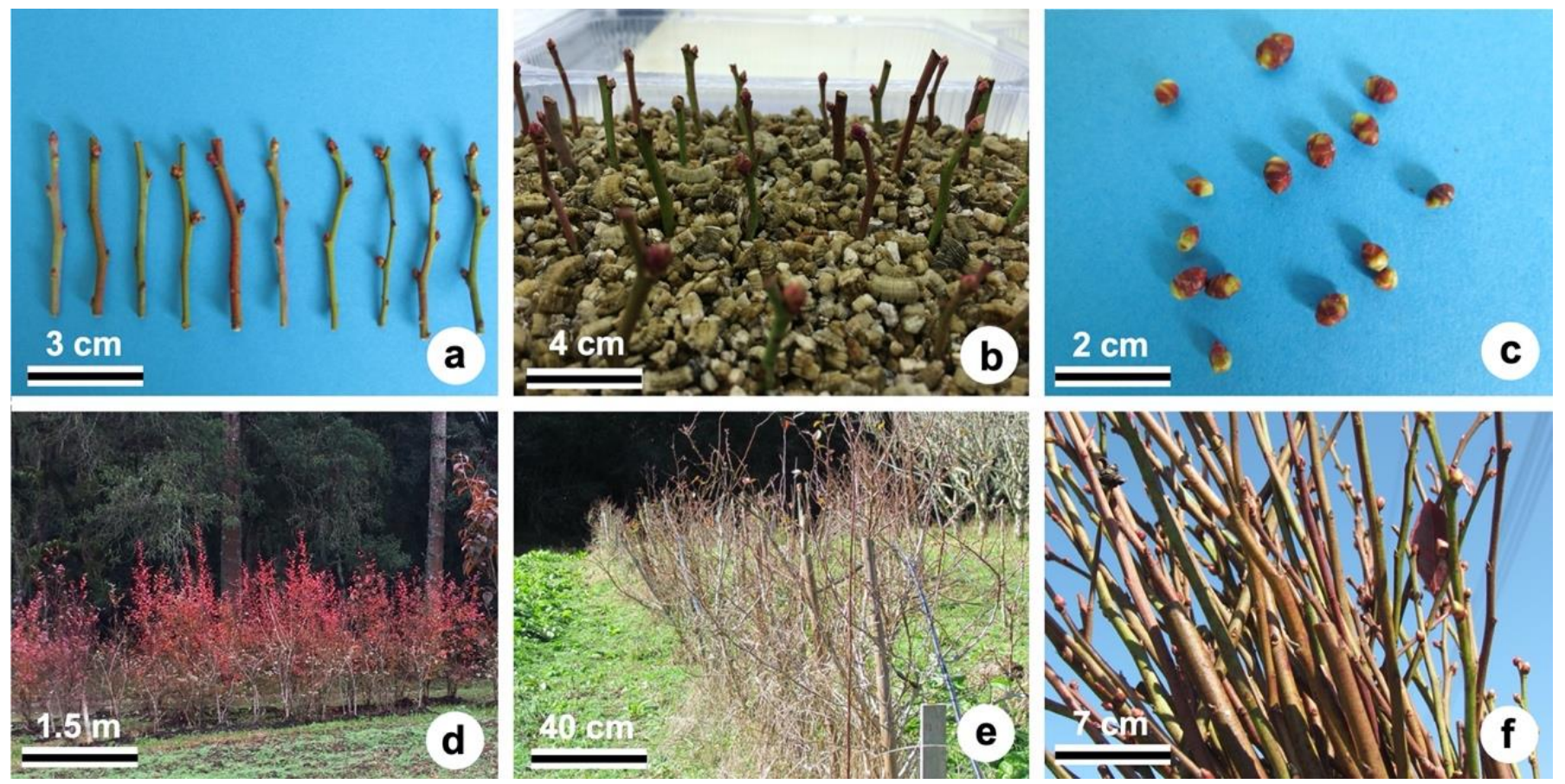

Figure 3. Blueberry dormancy evaluation. (a) $5 \mathrm{~cm}$ cuttings prepared for the biological test. (b) Single-node cuttings in the biological test. (c) Floral buds removed for hydric status evaluation. (d) Blueberry field on June 20, 2016. (e) Blueberry field on July 18, 2016. (f) Cuttings collected on August 1, 2016, for the biological test.

Cuttings were placed in a plastic box, in vermiculite substrate and maintained moistened (Figure 3b). Each plastic box contained 40 cuttings and was placed in a culture room under forcing conditions to sprout $\left(25^{\circ} \mathrm{C} \pm 2{ }^{\circ} \mathrm{C}\right.$ under a 16 -hour photoperiod with a light intensity of $40 \mu \mathrm{mol} \mathrm{m} \mathrm{m}^{-2} \mathrm{~s}^{-1}$ provided by cool-day fluorescent lamps). Cuttings were individually observed and recorded three times a week, for 40 days. Stages were observed according to three developmental floral bud stages: dormant winter bud, green tip bud, and opened bud (Figure 4) [adapted from 32]. Dormant winter bud (DW) refers to the state when buds are collected, with no visible swelling and no signs of growth (Figure 4a). Green tip bud (GT) shows the first sign of swelling and growth, with a green tip noticeable in the bud (Figure 4b). Opened bud (OB) shows a wider area of green tissue in the bud and increased swelling, individual flowers can be seen between the bud scales (Figure 4c).
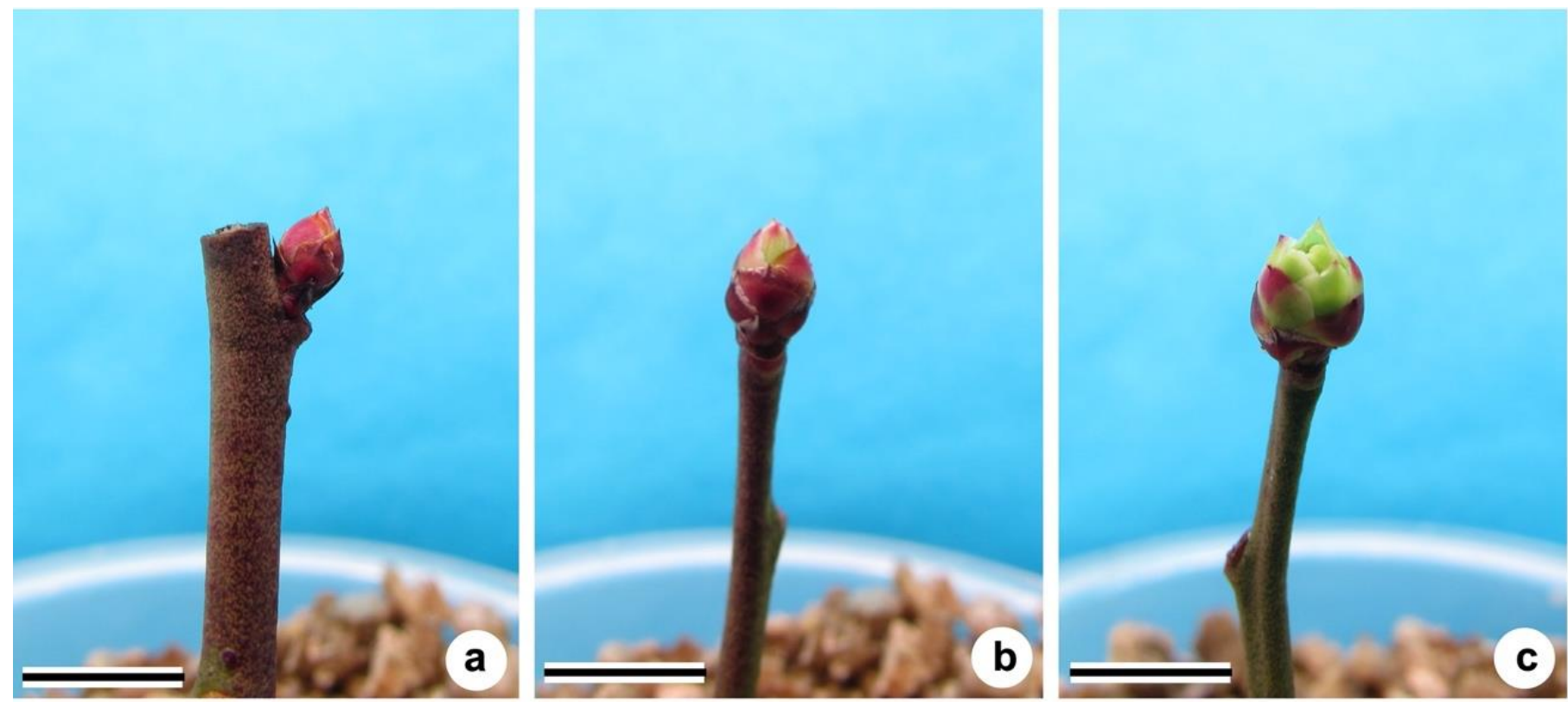

Figure 4. Developmental floral bud stages in blueberry: a) dormant winter bud (DW), b) green tip bud (GT), and c) opened bud $(\mathrm{OB})$. Scale bars $=1 \mathrm{~cm}$. 
The time to budburst was recorded when green tip bud was first visible (Figure 4b). The mean time to budburst (MTB), in days, reflects the average number of days that individual buds lapse from collecting to budburst (number of days that DW buds took from the date of collecting and the date GT was observed). It was calculated as follows:

$$
M T B=\frac{\sum\left(n G T_{i} \times t_{i}\right)}{G T}
$$

Where:

$n G T_{i}=$ number of buds that achieved the green tip stage at a certain time "i" ( $\mathrm{i}=1$ to 40$)$;

$t_{i}=$ number of days " $\mathrm{i}$ " ( $\mathrm{i}=1$ to 40 ), from the beginning of the experiment to a certain date where the green tip was observed

$G T=$ total number of buds that achieved green tip stage.

The final budburst rate (FBR) reflects the percentage of buds that achieved the green tip bud stage related to the number of initial dormant winter buds, in \%.

$$
F B R=\frac{G T \times 100}{W D}
$$

Where:

$G T=$ number of buds that achieved the green tip stage;

$D W=$ number of initial dormant winter buds in the experiment.

For the velocity of budburst (VB), it is calculated the average time that buds took from the beginning of the experiment to achieve the GT stage, calculated in buds.days ${ }^{-1}$.

$$
V B=\sum \frac{n G T_{i}}{t_{i}}
$$

Where:

$n G T_{i}=$ number of buds that achieved the green tip stage at a certain time "i" ( $i=1$ to 40 );

$t_{i}=$ number of days " $\mathrm{i}$ " ( $\mathrm{i}=1$ to 40 ), from the beginning of the experiment to a certain date where the green tip was observed.

Vigorous budburst rate (VBR) refers to the percentage of buds that reached the OB stage divided by the number of buds that had previously achieved the GT stage, in \%.

$$
V B R=\frac{O B \times 100}{G T}
$$

Where:

$O B=$ number of buds that achieved the opened bud stage;

$G T=$ number of buds that achieved the green tip stage;

\section{Relative water content (RWC) and water content (WC) in the floral buds}

The relative water content (RWC) was evaluated, weighing 45 floral buds per cultivar in each sampling date. The fresh weight $(\mathrm{mg})$ was recorded the same day the buds were collected, and the dry weight (mg) was evaluated three days after remaining in a drying chamber at $60^{\circ} \mathrm{C}$. The difference was divided by the fresh weight and multiplied by 100 to give a \% result.

The water content (WC) was calculated by the difference between fresh weight and dry weight divided by dry weight and was expressed in $\mathrm{g}$ water. $\mathrm{g}^{-1}$ bud dry weight.

\section{Chilling accumulation}

The environmental conditions were estimated using data from Simepar - Pinhais Meteorological Station, hourly measured. The chilling hours' estimation was made calculating the numbers of hours of temperature below or equal to $7.2^{\circ} \mathrm{C}$ between each of the periods, and accumulating them in each period. The temperatures hourly measured were also converted to chill units for the period evaluated and also accumulated, according to the Utah Chill Unit Model [1], the Modified Utah Chill Unit Model [2], and the Blueberry Model [3]. According to the Utah Model [1], positive chill-units begin to accumulate just after the day in the fall when the negative accumulation is experienced. 
In the three models, negative units (higher temperatures) started to be recorded after the first day with positive units (lower temperatures) only. In this work, it occurred on April 27, 2016, for the first two models and on April 26, 2016, for the Blueberry Model. Moreover, according to the Modified Utah Model [2], the negative units (higher temperatures) were used only until a maximum of 96 consecutive hours. The negative units could be accumulated again only after a positive chill unit (lower temperature) occurred.

Table 1. Conversion of temperatures to chill units according to the Utah Chill Unit Model [1] and according to the Blueberry Model [3].

\begin{tabular}{|c|c|c|c|c|}
\hline \multicolumn{3}{|c|}{ Utah Chill Unit Model } & \multicolumn{2}{|c|}{ Blueberry Model } \\
\hline Temperature & & Chill units & Temperature & Chill units \\
\hline oC & oF & & $\stackrel{\circ}{C}$ & \\
\hline$<1.4$ & $<34$ & 0 & $<2$ & 0 \\
\hline 1.5 to 2.4 & 35 to 36 & 0.5 & 3 to 5 & 0.5 \\
\hline 2.5 to 9.1 & 37 to 48 & 1 & 6 to 15 & 1 \\
\hline 9.2 to 12.4 & 49 to 54 & 0.5 & 15 to 18 & 0.5 \\
\hline 12.5 to 15.9 & 55 to 60 & 0 & 19 to 21 & 0 \\
\hline 16.0 to 18.0 & 61 to 65 & -0.5 & 22 to 24 & -0.5 \\
\hline$>18.0$ & $>65$ & -1 & $>25$ & -1 \\
\hline
\end{tabular}

\section{Experimental design, data collection, and statistical analysis}

The experiments for the single-node biological test were conducted in a completely randomized design using a two-factor experiment $(4 \times 8)$, with four different cultivars and eight different sampling dates. There were 32 treatments in total; each treatment contained ten cuttings and was replicated four times (40 cuttings per treatment). Resulting in a total of 1,280 cuttings. All the plants were evaluated, and the means in each replication were estimated. Subsequently, the mean of the four replications in each treatment was calculated.

The variables MTB (days), FBR (\%), velocity of budburst (buds.days ${ }^{-1}$ ), and vigorous budburst rate (\%) were square-root transformed before analyses. Two-way ANOVA was performed to detect any interaction between 2 factors and to check about the statistically significant difference between treatments. In all the variables analyzed, the interaction between the two factors (cultivars and sampling dates) was detected ( $p<$ 0.01). First, Tukey's test $(p<0.05)$ was performed for each of the sampling dates, inside each of the cultivars, and also Tukey's test $(p<0.05)$ was performed for each sampling date, inside each cultivar. Results were shown in a table where means followed by the same uppercase letter in the same column, and by the same lowercase letter in the horizontal lines are not statistically different.

For relative water content and water content evaluation, the experiment was a completely randomized design using a two-factor experiment $(4 \times 8)$, with four different cultivars and eight different sampling dates. There were 32 treatments in total; each treatment contained 15 floral buds and was replicated three times (45 buds per treatment), totalizing 1,440 buds. All the buds were measured, and ANOVA and Tukey's test were used as described above for the other experiment.

For these analyses, the software Assistat was used. Plants and buds in the culture room were taken pictures using a Canon PowerShot SX30 IS camera. Digital images were saved in JPG format with a resolution of $4320 \times 3240$ pixels. 


\section{RESULTS}

The number of chilling hours and chill units occurring during the period of the experiment can be observed in Table 2. It was recorded a total of 212 chilling hours, that corresponded to an accumulation of 267 chill units using the Utah Model, 393 chill units using de Modified Utah Model, and 1676.5 chill units using the Blueberry Model. Until the date of the first sampling (April 25), no chilling hours or chill units were recorded. Lower temperatures were recorded starting in the second period (from April 25 to May 9), where 44 chilling hours were seen, 32.5 chill units using the Utah Model, 48.5 using the Modified Utah Model, and 201.5 chill units in the Blueberry Model. The third (May 9 to May 23) and fourth (May 23 to May 6) periods did not show many low temperatures, totalizing 0 chilling hours and -43.5 and 16.5 chill units, respectively, using the Utah Model, and 8.0 and 20.5 chill units, respectively, using the Modified Utah Model. However, the Blueberry Model presented 239.0 and 284.5 chill units, respectively.

On the other hand, on the fifth (June 6 to June 20) and the sixth (June 20 to July 4) periods, chilling hours were 90 and 19 hours, respectively, and chill units were 121.5 and 86.5, respectively, using both the Utah Model and the Modified Utah Model. While the Blueberry Model presented 246.5 and 272.0 chill units. In the seventh period (July 4 to July 18), 33 chilling hours were observed, but negative chill units (-46.5) in the Utah Model and 8.0 chill units in the Modified Utah Model. The Blueberry Model kept registering positive chilling units (169.0). Moreover, finally, in the eighth period (July 18 to August 1), 26 chilling hours were observed corresponding to 100 chill units in both the Utah Model and the Modified Utah Model and 265.0 chill units in the Blueberry Model.

Table 2. Chilling hours $\left(\leq 7.2^{\circ} \mathrm{C}\right)$ and chill units calculated using the Utah Model (Richardson at al., 1974), the Modified Utah Model (Ebert at al., 1986), and the Blueberry Model [3], Pinhais/Paraná/Brazil, 2016. Abbreviation: accum., accumulated.

\begin{tabular}{lllllllll}
\hline & \multicolumn{2}{c}{$\begin{array}{c}\text { Chilling Hours } \\
\text { (n. hours } \mathbf{S} \mathbf{7 . 2} \mathbf{~} \mathbf{C})\end{array}$} & \multicolumn{2}{c}{$\begin{array}{c}\text { Chill Units } \\
\text { (Utah Model) }\end{array}$} & \multicolumn{2}{c}{$\begin{array}{c}\text { Chill Units } \\
\text { (Modified Utah } \\
\text { Model) }\end{array}$} & $\begin{array}{c}\text { Chill Units } \\
\text { (Blueberry Model) }\end{array}$ \\
\cline { 2 - 9 } Period & Period & Accum. & Period & Accum. & Period & Accum. & Period & Accum. \\
\hline April 01-April 25 & 0.0 & 0.0 & 0.0 & 0.0 & 0.0 & 0.0 & 0.0 & 0.0 \\
April 25-May 9 & 44.0 & 44.0 & 32.5 & 32.5 & 48.5 & 48.5 & 201.5 & 201.5 \\
May 9-May 23 & 0.0 & 44.0 & -43.5 & -11.0 & 8.0 & 56.5 & 239.0 & 440.5 \\
May 23-June 6 & 0.0 & 44.0 & 16.5 & 5.5 & 20.5 & 77.0 & 284.5 & 725.0 \\
June 6-June 20 & 90.0 & 134.0 & 121.5 & 127.0 & 121.5 & 198.5 & 246.5 & 971.5 \\
June 20-July 4 & 19.0 & 153.0 & 86.5 & 213.5 & 86.5 & 285.0 & 272.0 & 1243.5 \\
July 4-July 18 & 33.0 & 186.0 & -46.5 & 167.0 & 8.0 & 293.0 & 168.0 & 1411.5 \\
July 18-August 1 & 26.0 & 212.0 & 100.0 & 267.0 & 100.0 & 393.0 & 265.0 & 1676.5 \\
\hline
\end{tabular}

The progression of MTB in the four cultivars can be observed in Table 3. The four cultivars had similar behavior, showing that MTB decreased along with the experiments. The first sampling date did not show any budburst for 'Bluegem', 'Climax', and 'Powderblue'. Only 'Delite' showed an MTB of 32.3 days during the first period. During the fall and winter, MTB decreased in all the cultivars, reaching an average of 2.8 days in the last period analyzed for the four cultivars.

The FBR (Table 3) details the results in the four cultivars, showing that 'Delite' had higher FBR in the initial periods comparing to the other cultivars. However, considering the middle of the observations and the end of the experiment, the four cultivars had a similar pattern. For all the cultivars, the initial sampling dates showed lower FBR, which increased during the time. It was possible to observe that the four cultivars analyzed were released from dormancy by the end of the experiment, reaching FBR rates from 97.50 and $100.0 \%$. 
Table 3. Mean time to budburst (MTB) in days and final budburst rate (FBR) in \% in the single-node cuttings biological test performed with 'Bluegem', 'Climax', 'Delite' and 'Powderblue' rabbiteye blueberry cultivars collected in Pinhais/PR/Brazil, 2016.

\begin{tabular}{|c|c|c|c|c|c|c|c|c|c|c|}
\hline \multicolumn{11}{|c|}{ Mean time to budburst (MTB) days } \\
\hline $\begin{array}{l}\text { Sampling } \\
\text { date }\end{array}$ & \multicolumn{2}{|c|}{ Bluegem } & \multicolumn{2}{|c|}{ Climax } & \multicolumn{3}{|c|}{ Delite } & \multicolumn{2}{|c|}{ Powderblue } & Mean \\
\hline April 25 & & $\bar{A}$ & & $\bar{A}$ & 32.3 & & $\bar{A}$ & & $\bar{A}$ & 32.3 \\
\hline May 9 & $\overline{30.4} \mathrm{a}$ & B & $\overline{25.3} \mathrm{ab}$ & B & 23.8 & b & B & $\overline{25.9} a b$ & B & 26.4 \\
\hline May 23 & $17.0 \mathrm{~b}$ & $\mathrm{C}$ & $14.2 \mathrm{bc}$ & C & 11.5 & c & $\mathrm{C}$ & 24.9 a & B & 16.9 \\
\hline June 6 & $14.6 \mathrm{a}$ & C & $9.0 \mathrm{~b}$ & $\mathrm{D}$ & 10.0 & $\mathrm{~b}$ & CD & $11.6 \mathrm{ab}$ & $\mathrm{C}$ & 11.3 \\
\hline June 20 & $8.1 \mathrm{c}$ & D & $14.3 \mathrm{ab}$ & C & 10.3 & bc & $C D$ & $15.6 \mathrm{a}$ & C & 12.1 \\
\hline July 4 & $3.8 \mathrm{~b}$ & $\mathrm{E}$ & $4.3 \mathrm{~b}$ & $\mathrm{E}$ & 7.5 & a & D & $4.5 \mathrm{~b}$ & D & 5.0 \\
\hline July 18 & $7.6 \mathrm{a}$ & D & $8.1 \mathrm{a}$ & D & 6.5 & a & $\mathrm{D}$ & $3.7 \mathrm{~b}$ & D & 6.5 \\
\hline Auqust 1 & $3.3 \mathrm{a}$ & $\mathrm{E}$ & $2.5 \mathrm{a}$ & $\mathrm{E}$ & 3.0 & a & $\mathrm{E}$ & $2.1 \mathrm{a}$ & D & 2.8 \\
\hline CV\% & 8.6 & & & & & & & & & \\
\hline \multicolumn{11}{|c|}{ Final budburst rate (FBR) in $\%$} \\
\hline $\begin{array}{l}\text { Sampling } \\
\text { date }\end{array}$ & \multicolumn{2}{|c|}{ Bluegem } & \multicolumn{2}{|c|}{ Climax } & \multicolumn{3}{|c|}{ Delite } & \multicolumn{2}{|c|}{ Powderblue } & Mean \\
\hline April 25 & $0.0 \mathrm{~b}$ & $\bar{D}$ & $0.0 \mathrm{~b}$ & $\bar{D}$ & 57.5 & $\bar{a}$ & $\overline{C D}$ & $0.0 \mathrm{~b}$ & $\bar{D}$ & 14.4 \\
\hline May 9 & $17.5 \mathrm{bc}$ & C & $10.0 \mathrm{c}$ & C & 55.0 & $a$ & $\mathrm{D}$ & $25.0 \mathrm{~b}$ & C & 26.9 \\
\hline May 23 & $26.7 \mathrm{~b}$ & C & $20.0 \mathrm{~b}$ & C & 82.5 & a & $A B C$ & $30.0 \mathrm{~b}$ & C & 39.8 \\
\hline June 6 & $67.5 \mathrm{ab}$ & B & $22.5 \mathrm{c}$ & $B C$ & 90.0 & $a$ & $A B$ & $65.0 \mathrm{~b}$ & B & 61.3 \\
\hline June 20 & $70.0 \mathrm{a}$ & $A B$ & 40.0 b & B & 80.0 & a & ABCD & $77.5 \mathrm{a}$ & $A B$ & 66.9 \\
\hline July 4 & $67.5 \mathrm{bc}$ & B & $90.0 \mathrm{ab}$ & A & 62.5 & c & BCD & $92.5 \mathrm{a}$ & $A B$ & 78.1 \\
\hline July 18 & $97.5 \mathrm{a}$ & $A$ & $92.5 \mathrm{a}$ & A & 100.0 & a & A & $100.0 \mathrm{a}$ & $A$ & 97.5 \\
\hline August 1 & $97.5 \mathrm{a}$ & A & $100.0 \mathrm{a}$ & A & 100.0 & a & A & $100.0 \mathrm{a}$ & A & 99.4 \\
\hline CV\% & 10.6 & & & & & & & & & \\
\hline
\end{tabular}

Means followed by the same lowercase letter within the horizontal line and the uppercase letter within the column are not significantly different according to Tukey's test $(p<0,05)$.

It is possible to observe that the initial sampling dates showed a lower velocity of budburst than the final sampling dates (Table 4). The final sampling date showed higher velocity, with numbers varying from 4.28 to 4.91 buds per day. It was also noticed that, in all the cultivars, the initial sampling dates treatments presented much lower rates than those vigorous budburst rate observed along the time, especially from June until the end of the experiments (Table 4). By June 20, it was observed that $71.4 \%$ (Bluegem) to $100.0 \%$ (Powderblue) of green tip buds (GT) reached the open flower bud (OB) stage. Besides, all the four cultivars presented a vigorous budburst rate of $100 \%$ at some point of the experiment. This maximum rate was achieved at different sampling dates by the cultivars. In Powderblue, 100\% green tip buds (GT) reached the opened flower bud stage (OB) in June 20. In Bluegem and Climax, 100\% green tip buds (GT) reached the opened flower bud (OB) stage at July 4. And in Delite, this happened in July 18 (Table 4). 
Table 4. Velocity of budburst (VB) in buds.day ${ }^{-1}$ and vigorous budburst rate (VBR) in \%, in the single-node cuttings biological test performed with 'Bluegem', 'Climax', 'Delite' and 'Powderblue' rabbiteye blueberry cultivars collected in Pinhais/PR/Brazil, 2016.

\begin{tabular}{|c|c|c|c|c|c|c|c|c|c|c|c|c|}
\hline \multicolumn{13}{|c|}{${\text { Velocity of budburst (VB) in buds.day }{ }^{-1}}^{-1}$} \\
\hline Sampling date & \multicolumn{3}{|c|}{ Bluegem } & \multicolumn{3}{|c|}{ Climax } & \multicolumn{3}{|c|}{ Delite } & \multicolumn{2}{|c|}{ Powderblue } & Mean \\
\hline April 25 & & & $\mathrm{~F}$ & & & $\mathrm{~F}$ & 0.18 & & $\mathrm{D}$ & & $\mathrm{F}$ & 0.18 \\
\hline May 9 & $\overline{0.06}$ & b & $\mathrm{EF}$ & $\overline{0.04}$ & b & $\mathrm{EF}$ & 0.25 & a & $\mathrm{D}$ & $\overline{0.10} \mathrm{ab}$ & EF & 0.11 \\
\hline May 23 & 0.20 & b & $\mathrm{E}$ & 0.17 & $\mathrm{~b}$ & $\mathrm{DE}$ & 0.78 & a & $\mathrm{C}$ & $0.13 \mathrm{~b}$ & $\mathrm{E}$ & 0.32 \\
\hline June 6 & 0.57 & b & D & 0.34 & $\mathrm{~b}$ & D & 1.09 & a & C & $0.60 \mathrm{~b}$ & D & 0.65 \\
\hline June 20 & 1.27 & a & C & 0.35 & c & D & 0.92 & $a b$ & C & $0.69 \mathrm{~b}$ & D & 0.81 \\
\hline July 4 & 1.96 & b & B & 2.56 & a & B & 1.10 & $\mathrm{c}$ & C & $2.51 \mathrm{ab}$ & C & 2.03 \\
\hline July 18 & 1.35 & b & $\mathrm{BC}$ & 1.65 & $\mathrm{~b}$ & C & 1.83 & b & B & $3.43 \mathrm{a}$ & B & 2.06 \\
\hline Auqust 1 & 4.28 & a & A & 4.60 & $\mathrm{a}$ & A & 4.51 & $\mathrm{a}$ & A & $4.91 \mathrm{a}$ & A & 4.58 \\
\hline CV\% & 12.14 & & & & & & & & & & & \\
\hline \multicolumn{13}{|c|}{ Vigorous budburst rate (VBR) in \% } \\
\hline Sampling date & \multicolumn{3}{|c|}{ Bluegem } & \multicolumn{3}{|c|}{ Climax } & \multicolumn{3}{|c|}{ Delite } & \multicolumn{2}{|c|}{ Powderblue } & Mean \\
\hline April 25 & 0.0 & $\mathrm{a}$ & $\bar{B}$ & 0.0 & $a$ & $\mathrm{C}$ & 0.0 & $\mathrm{a}$ & $\mathrm{B}$ & $0.0 \mathrm{a}$ & $\mathrm{B}$ & 0.0 \\
\hline May 9 & 0.0 & a & B & 0.0 & $\mathrm{a}$ & C & 0.0 & a & $\mathrm{B}$ & $0.0 \mathrm{a}$ & $\mathrm{B}$ & 0.0 \\
\hline May 23 & 6.3 & b & $B$ & 58.3 & $a$ & B & 0.0 & $\mathrm{~b}$ & B & $5.0 \mathrm{~b}$ & B & 17.4 \\
\hline June 6 & 9.1 & $\mathrm{c}$ & B & 41.7 & $a b$ & B & 11.4 & $\mathrm{bc}$ & $\mathrm{B}$ & $61.9 \mathrm{a}$ & A & 31.0 \\
\hline June 20 & 71.4 & a & A & 88.8 & $a$ & A & 72.9 & $\mathrm{a}$ & A & $100.0 \mathrm{a}$ & A & 83.3 \\
\hline July 4 & 100.0 & a & A & 100.0 & $a$ & A & 80.2 & a & A & $100.0 \mathrm{a}$ & A & 95.1 \\
\hline July 18 & 95.0 & a & A & 100.0 & $a$ & A & 100.0 & a & A & $100.0 \mathrm{a}$ & A & 98.8 \\
\hline Auqust 1 & 89.4 & a & A & 97.5 & $\mathrm{a}$ & A & 97.5 & a & A & $100.0 \mathrm{a}$ & A & 96.1 \\
\hline CV\% & 30.0 & & & & & & & & & & & \\
\hline
\end{tabular}

Means followed by the same lowercase letter within the horizontal line and the uppercase letter within the column are not significantly different according to Tukey's test $(p<0,05)$.

The analyzed variables relative water content and water content (Table 5) also showed that in the initial treatments the water was lower than in the final treatments, showing that at the beginning of the winter, the floral buds had less relative water content and less water content than at the end of the experiment.

Table 5. Relative water content (RWC) in \% and water content (WC) in the floral buds with 'Bluegem', 'Climax', 'Delite', and 'Powderblue' rabbiteye blueberry cultivars collected in Pinhais/PR/Brazil, 2016.

Relative Water Content (RWC) in \%

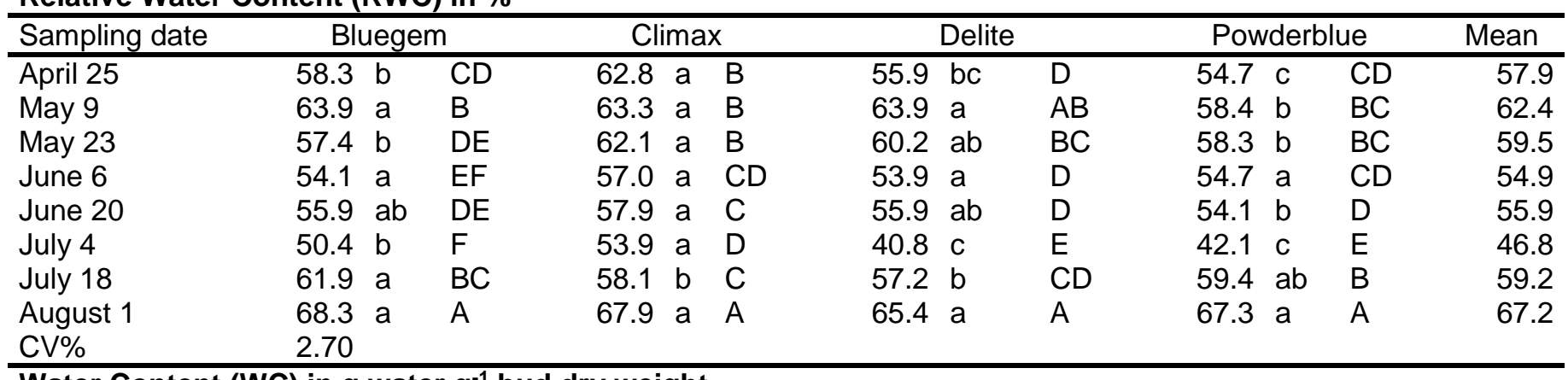

\section{Water Content (WC) in $\mathrm{g}$ water.g $\mathrm{g}^{-1}$ bud dry weight}

\begin{tabular}{|c|c|c|c|c|c|c|c|c|c|c|c|c|c|}
\hline Sampling date & Blu & legem & & Clim & nax & & & Delite & & Powc & derb & & Mean \\
\hline April 25 & 1.40 & $\bar{b}$ & $\mathrm{C}$ & 1.69 & $\bar{a} B$ & $\bar{B}$ & 1.27 & $\mathrm{~b}$ & C & 1.21 & $\mathrm{~b}$ & $\mathrm{C}$ & 1.39 \\
\hline May 9 & 1.78 & a & B & 1.73 & B & $B$ & 1.77 & a & A & 1.40 & b & $B C$ & 1.67 \\
\hline May 23 & 1.35 & b & C & 1.64 & $\mathrm{a}$ & $B$ & 1.51 & $a b$ & B & 1.40 & b & $B C$ & 1.48 \\
\hline June 6 & 1.18 & $\mathrm{a}$ & $C D$ & 1.33 & $\mathrm{a}$ & C & 1.17 & $\mathrm{a}$ & C & 1.21 & a & C & 1.22 \\
\hline June 20 & 1.27 & $a b$ & C & 1.38 & a & C & 1.27 & $a b$ & C & 1.18 & b & C & 1.27 \\
\hline July 4 & 1.03 & $\mathrm{a}$ & D & 1.17 & $\mathrm{a}$ & C & 0.69 & b & D & 0.73 & b & D & 0.90 \\
\hline July 18 & 1.63 & a & B & $1.38 k$ & $b$ & C & 1.34 & b & $B C$ & 1.46 & $a b$ & B & 1.45 \\
\hline August 1 & 2.16 & a & A & 2.12 & $a$ & A & 1.89 & b & A & 2.06 & $a b$ & A & 2.06 \\
\hline CV\% & 6.30 & & & & & & & & & & & & \\
\hline
\end{tabular}

Means followed by the same lowercase letter within the horizontal line and the uppercase letter within the column are not significantly different according to Tukey's test $(p<0,05)$. 
Figure 5 shows the dormancy dynamics of each cultivar along the experiment, referring to the chill units accumulated in each of the periods of the experiment.
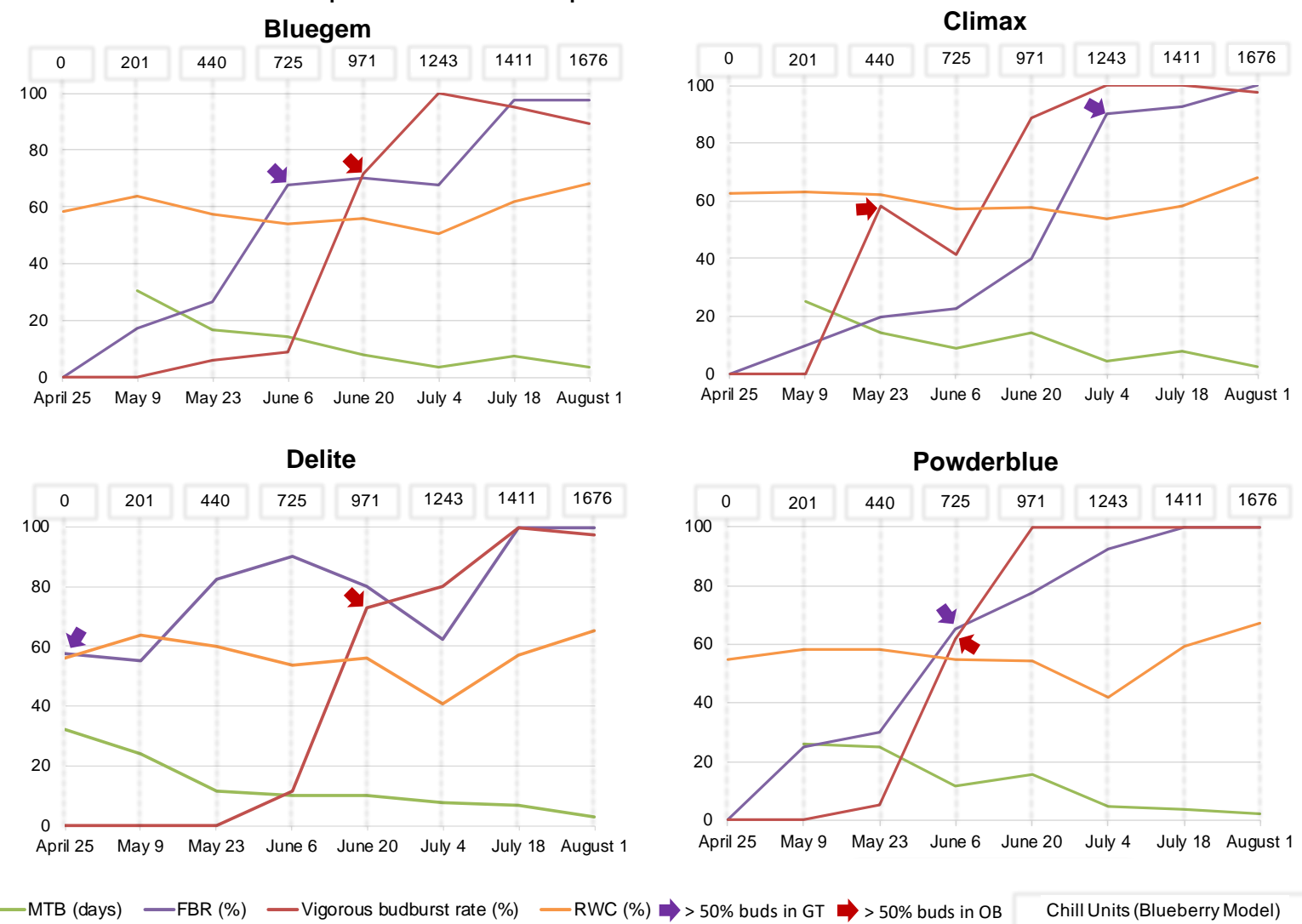

Figure 5. Comparison of chill units calculated with the Blueberry Model [3] along the experiment and four variables evaluated in the eight sampling dates: MTB in days, FBR in \%, Vigorous budburst rate in \%, RWC in \%, and sampling dates where at least $50 \%$ of the initial DW buds reached GT stage (purple arrow) and where at least $50 \%$ of the GT buds reach the OB stage (red arrow), in the single-node cuttings biological test performed with 'Bluegem', 'Climax', 'Delite' and 'Powderblue' rabbiteye blueberry cultivars collected in Pinhais/PR/Brazil, 2016. Abbreviations: DW, dormant winter buds; FBR, final budburst rate; GT, green tip bud stage; MTB, mean time to budburst; OB, opened bud stage; RWC, relative water content.

In Table 6 the cultivars are shown, and respective chilling hours and chill units required for at least $50 \%$ of green tip buds to reach the opened bud stage.

Bluegem and Delite required 134.0 chilling hours, 127.0 chill units (Utah Model), 198.5 chill units (Modified Utah Model), and 971.5 chill units (Blueberry Model). Climax required 44.0 chilling hours, -11.0 chill units (Utah Model), 56.5 chill units (Modified Utah Model), and 440.5 chill units (Blueberry Model). And Powderblue required 44.0 chilling hours, 5.5 chill units (Utah Model), 77.0 chill units (Modified Utah Model), and 725.0 chill units (Blueberry Model).

Table 6. Rabbiteye blueberry cultivars 'Bluegem', 'Climax', 'Delite', and 'Powderblue' chilling requirement to opened bud stage in Pinhais/PR/Brazil, 2016, according to chilling hours and chill units estimations compared to the literature. Abbreviations: GT, green tip bud stage; OB, opened bud stage.

\begin{tabular}{lcccccc}
\hline Cultivars & $\begin{array}{c}\text { Sampling date } \\
\text { when 50\% of } \\
\text { GT buds reach } \\
\text { OB stage }\end{array}$ & $\begin{array}{c}\text { Chilling } \\
\text { Hours } \text { (n. } \\
\text { hours } \leq \mathbf{7 . 2} \\
\text { o-C) }\end{array}$ & $\begin{array}{c}\text { Chill Units } \\
\text { (Utah Model) }\end{array}$ & $\begin{array}{c}\text { Chill Units } \\
\text { (Modified } \\
\text { Utah } \\
\text { Model) }\end{array}$ & $\begin{array}{c}\text { Chill Units } \\
\text { (Blueberry } \\
\text { Model) }\end{array}$ & Literature \\
\hline Bluegem & June 20 & 134.0 & 127.0 & 198.5 & 971.5 & $400[24]$ \\
Climax & May 23 & 44.0 & -11.0 & 56.5 & 440.5 & $400[24]$ \\
Delite & June 20 & 134.0 & 127.0 & 198.5 & 971.5 & $500[24]$ \\
Powderblue & June 6 & 44.0 & 5.5 & 77.0 & 725.0 & $550-600[33]$ \\
\hline
\end{tabular}




\section{DISCUSSION}

The chilling requirements have represented major problems for blueberry production in warmer winter regions [33]. Moreover, considering global climate changing, understanding the dormancy mechanisms, and chilling requirements are of crucial importance for the sustainable production of temperate crops [34].

Different species and different cultivars have a significant variation in chilling requirements $[35,36]$. Rabbiteye and southern highbush cultivars usually require fewer chilling hours for budbreak and flowering than northern highbush cultivars [37]. According to the literature, 'Climax' is around 400 chilling hours, 'Delite' around 500 hours, and 'Powderblue' requires 550-600 hours [24], while 'Bluegem' ranges around 400 hours [38]. However, these values represent an estimate and are not accurate to every region of interest [33]. Furthermore, it is difficult to achieve a precise determination of chilling requirements under field conditions for breaking dormancy, due to many factors not controlled, like radiation and oscillations in temperature [39]. Also, different combinations of chilling and forcing may explain different chilling values determined in each region [40].

In the present study, the Blueberry Model estimated more chill units (in a total of 1676.5 chill units until the end of the experiment) than the Utah Model (a total of 267.0 chill units until the end of the experiment) and the Modified Utah Model (393.0 chill units). According to the Blueberry Model, by May 23, the number of chilling units achieved was 440.50 , and, by June 6 , a total of 725.0 chill units were recorded. These results seem to be a closer estimation of chilling units related to the rabbiteye cultivars requirement presented in the literature. The present work showed that the highest FBR in Delite was achieved around May 23; Powderblue and Bluegem in June 20, and Climax in July 4. Our results are consistent with the highlighted in a study with apple buds, which shows that dormancy (its entrance and its highest level) are correlated with cold winter temperatures [17].

According to the highest FBR, it was observed that Delite was more precocious than Bluegem, Climax, and Powderblue, presenting $82.5 \%$ FBR on May 23, while the other cultivars had FBR around $20-30 \%$ at this sampling date, showing in this study a possibility of lower requirement in chilling units by Delite (Table 3 ). However, the vigorous budburst rate indicated that, only in the sampling dates from June 20 and subsequent ones, Delite showed higher rates (72.9-100.0\%) (Table 4). Besides, the MTB in Delite showed a decrease on June 6 , but reached 3.0 days to budburst only on August 1, indicating that despite being precocious, it showed a slower pace in the dormancy dynamics (Table 3). Keeping on observing the FBR, Delite had at least $50 \%$ of DW buds reaching GT stage earlier than the other cultivars, on April 25. Bluegem and Powderblue had at least $50 \%$ of their DW buds reaching this stage only on June 6 . And Climax on July 4 (Figure 5).

Considering the dynamics of the MTB observed in these rabbiteye cultivars, data is in accordance with work in apricot [10], where the MTB showed a rapid decrease as soon as the dormancy break occurred. Additionally, the FBR followed a pattern similar to the study in grapes, where the FBR stayed elevated from June until August [20]. Concerning the velocity of budburst, our results are similar to the ones in the experiment with grape [20], where the highest velocity of budburst was found in the last days of sampling, showing the releasing of dormancy.

Observing the vigorous budburst rate, Climax evolved faster and $50 \%$ of GT buds in Climax reached OB stage on May 23, before the other cultivars. Powderblue reached this stage on June 6 and Bluegem and Delite on June 20.

Evaluating the RWC and WC in the floral buds, the higher rates were observed at the beginning of the experiment and at the end. They were observed in the first and second sampling dates, depending on the cultivar analyzed. Then, these rates tended to have lower values along with the experiment and a new increase at the last or the last two sampling dates. This increase in the relative water content and water content coincided with the end of the dormancy period. This data confirms that dormancy is also represented by a physical and morphological barrier, impeding the meristem to receive water. These findings are congruent with the research in peach flower buds, where it was found that, at the end of the endodormancy, the floral buds showed activation of inter- and intracellular communication. The authors described that this activation was related to aquaporin membrane transport, leading to an increase in water content necessary for buds activity [41]. This activation of aquaporins leads to an increase in water content just before the bud restarts the growth [42]. Working with apples, the authors observed rehydration of the buds along with the endodormancy release and establishment of the ecodormancy stage, either in temperate or mild winter climates; with the difference that in the temperate region the rehydration of the apple buds were slower than in mild winter climate, and that this transition can be related to a progressive increase of the temperatures, 
to allow an active metabolism. One of the reasons to these differences would be the lower development rate of xylem vessel, and lower metabolic activity, with a delay in the development of the osmotic potential of the meristematic cells and their sink strength in trees in colder temperatures [17]. Another work, in cherry floral buds, links the relative water content to the phases of dormancy. It shows that the relative water content decreased during the phase of endodormancy and increased in the transition from endo- to ecodormancy, showing this rehydration of the floral buds coinciding with the achievement of the minimum chilling requirement of these cherry varieties [43]. The authors described in 'Packham' and 'Triumph' pear cultivars the same pattern in dormancy, observing that the new growth of buds coincided with a significant increase in their water content [44].

Some authors studied in sweet cherry the combination of chilling and forcing (subsequent warming period) effect on dormancy breaking, where extra forcing can partially substitute the lack of chilling and is an opportunity for low chilling regions to grow temperate fruit crops. In their study, the authors concluded that there is a need of a minimum chilling period before the forcing period to become effective on inducing buds to flower [40].

Some other possibilities for future research would be testing some new released southern highbush blueberry cultivars 'Atlasblue', 'Biancablue', and 'Jupiterblue' [45], to grow in an evergreen system. This system could be used in mild winter climates, due to geographical location or even concerned to climate changing scenarios. These cultivars require very low chilling to grow. And then, the flowering, fruiting and subsequent harvest season in the evergreen production can be controlled by different pruning and fertilization methods [37]. Some regions use this evergreen system to anticipate the harvesting period, to an off-season time (such as winter and early spring) [46]. This anticipation, however, is dependent on the absence of freezing temperatures that could damage the early developing flowers, at least during this period of development.

The present study evaluated and compared the dormancy dynamics in four rabbiteye blueberry cultivars during different periods of one-year fall/winter. In this way, additional research can be developed to increase more years and add more variability under different environmental conditions. Taking into account that literature shows that different temperatures before collecting the cuttings could modify the time to budburst [47], that cultural variables may influence the chilling response [29], we expect that future research can expand and deepen this knowledge, based on the promising results found here.

\section{CONCLUSION}

In summary, the data presented showed that the four cultivars had a dormancy release during the period evaluated in the experiments. It might indicate that the floral buds of these cultivars would meet their chilling requirements in the studied region. The four blueberry cultivars analyzed in this work showed that dormancy was deeper in the initial dates of sampling and started to decrease along with the fall and winter. In the initial sampling date of April 23, they showed no or very little budburst, and at the final dates (July and August) they showed numbers around $100 \%$ of FBR, lower MTB, higher velocity of budburst, higher percentage of vigorous budburst rate and also higher RWC and WC, showing that they had overcome dormancy. Despite some similar behavior of the four cultivars, it was possible to observe that 'Delite' had superior FBR in the first three dates of sampling (April and May), demonstrating that it had been released of dormancy earlier than 'Bluegem', 'Climax' and 'Powderblue'. This work represents an initial approach to dormancy in rabbiteye cultivars in mild winter regions and can be of valuable importance to be further explored in other geographical regions and with different blueberry cultivars.

Funding: This study was financed in part by Coordenação de Aperfeiçoamento de Pessoal de Nível Superior - Brasil (CAPES) - Finance Code 001 under a Ph.D. scholarship grant.

Acknowledgments: We are grateful to Kassius Augusto da Rosa for the support and collaboration at the laboratory work.

Conflicts of Interest: The authors declare no conflict of interest. The funders had no role in the design of the study; in the collection, analyses, or interpretation of data; in the writing of the manuscript, or in the decision to publish the results.

\section{REFERENCES}

1. Richardson EA, Seeley SD, Walker DR. A model for estimating the completion of rest for "Redhaven" and "Elberta" peach trees. HortScience. 1974;9(4):331-2.

2. Ebert A, Petri JL, Bender RJ, Braga HJ. First experiences with chill-unit models in Southern Brazil. Acta Hortic. 1986 May;184:79-86. 
3. Spiers JM. Chilling regimens affect bud break in 'Tifblue' rabbiteye blueberry. J Am Soc Hortic Sci. 1976;101(1):8890.

4. Horvath D. Common mechanisms regulate flowering and dormancy. Plant Sci. 2009;177(6):523-31.

5. Lang G, Early J, Martin G, Darnell R. Endo-, para-, and ecodormancy: physiological terminology and classification for dormancy research. Hort Science. 1987;22(3):371-7.

6. Balandier P, Bonhomme M, Rageau R, Capitan F, Parisot E. Leaf bud endodormancy release in peach trees: evaluation of temperature models in temperate and tropical climates. Agric For Meteorol. 1993 Dec;67(1-2):95113.

7. Bonhomme M, Rageau R, Richard JP, Gendraud M. Dormancy of peach floral buds: biological and tentative biochemical approaches. Acta Hortic. 1997 Dec;441:167-74.

8. Rageau R. Croissance et débourrement des bourgeons végétatifs de pêcher (Prunus persica L. Batsch) au cours d'un test classique de dormance. CR Acad Sci. 1978;287(Ser. D):1119-22.

9. Carvalho RIN, Biasi LA. Assessment of dormancy intensity in buds of temperate climate fruit species. In: Botelho R V., editor. Plant dormancy: mechanisms, causes and effects. Hauppauge, New York: Nova Science Publishers Inc.; 2019. p. 31-72.

10. Campoy JA, Ruiz D, Egea J. Seasonal progression of bud dormancy in apricot (Prunus armeniaca L.) in a Mediterranean climate: a single-node cutting approach. Plant Biosyst. 2011 Sep;145(3):596-605.

11. Carvalho RIN de, Biasi LA, Zanette F, Rendoke JC, Santos JM, Pereira GP. Endodormência de gemas de pessegueiro e ameixeira em região de baixa ocorrência de frio. Rev Bras Frutic. 2010 Sep;32(3):769-77.

12. Carvalho RIN de, Biasi LA. Índice para a avaliação da intensidade de dormência de gemas de fruteiras de clima temperado. Rev Bras Frutic. 2012 Sep;34(3):936-40.

13. Balandier P, Gendraud M, Rageau R, Bonhomme M, Richard JP, Parisot E. Bud break delay on single node cuttings and bud capacity for nucleotide accumulation as parameters for endo- and paradormancy in peach trees in a tropical climate. Sci Hortic. (Amsterdam). 1993;55(3-4):249-61.

14. Alves G, Biasi LA, May-De-Mio LL. Bud dormancy intensity in peach tree cultivars by biological and tetrazolium test. Rev Bras Frutic. 2016 Mar/Apr;38(2):e-956. Available from: https://doi.org/10.1590/0100-29452016956.

15. Carvalho RIN, Pereira GP, Prado AE, Biasi LA, Zanette F. Endodormancy of apple and pear buds in a region of low chill occurrence in Brazil. Acta Hortic. 2012 May;932:447-52.

16. Carvalho RIN de, Biasi LA, Zanette F, Rendoke JC, Santos JM, Pereira GP. Dormancy of "Imperial Gala" apple and "Hosui" pear tree buds in a region of low chill occurrence. Acta Sci Agron. 2014 Aug 21;36(4):429-34.

17. Malagi G, Sachet MR, Citadin I, Herter FG, Bonhomme M, Regnard JL, et al. The comparison of dormancy dynamics in apple trees grown under temperate and mild winter climates imposes a renewal of classical approaches. Trees - Struct Funct. 2015 Oct;29(5):1365-80.

18. Bonhomme $M$, Rageau $R$, Lacointe $A$. Optimization of endodormancy release models, using series of endodormancy release data collected in France. Acta Hortic. 2010 Aug;872:51-60.

19. Oukabli A, Mahhou A. Dormancy in sweet cherry (Prunus avium L.) under Mediterranean climatic conditions. Biotechnol Agron Soc Environ. 2007 Jan;11(2):133-9.

20. Biasi LA, Zanette F, Carvalho RIN. Dormancy dynamics of grape and kiwifruit buds in a region of low chill occurrence. Acta Hortic. 2012 May;932:507-12.

21. Rinne $P$, Tuominen $H$, Junttila $O$. Seasonal changes in bud dormancy in relation to bud morphology, water and starch content, and abscisic acid concentration in adult trees of Betula pubescens. Tree Physiol. 1994;14(6):54961.

22. Botelho RV, Ayub RA, Müller MML. Somatória de horas de frio e de unidades de frio em diferentes regiões do estado do Paraná. Sci Agrar. 2006 Dec;7(1-2):89-96.

23. Biggs RH. Fruit Notes. Newsletter 8. Gainesville; 1975.

24. Retamales JB, Hancock JF. Blueberries. Oxfordshire: CABI; 2012. 336 p.

25. Vander Kloet SP. The genus Vaccinium in North America [Internet]. Agriculture Canada. Ottawa: Agriculture Canada; 1988. 201 pp. Available from: https://trove.nla.gov.au/version/22638679

26. Song G, Chen Q. Comparative transcriptome analysis of nonchilled, chilled, and late-pink bud reveals flowering pathway genes involved in chilling-mediated flowering in blueberry. BMC Plant Biol. 2018 May;18:98. Available from: https://doi.org/10.1186/s12870-018-1311-8

27. Gilreath PR, Buchanan DW. Temperature and Cultivar Influences on the Chilling Period of Rabbiteye Blueberry. J Am Soc Hortic Sci. 1981;106(5):625-8.

28. Mainland CM, Buchanan DW, Bartholic JF. The effects of five chilling regimes on bud break of highbush (Vaccinium corymbosum L.) and Rabbiteye ( V. ashei Reade) blueberry hardwood cuttings. HortScience (abstract). 1977;12:43.

29. Norvell DJ, Moore JN. An evaluation of chilling models for estimating rest requirements of highbush blueberries 
(Vaccinium corymbosum L.). J Am Soc Hortic Sci. 1982;107(1):54-6.

30. Alvares CA, Stape JL, Sentelhas PC, de Moraes Gonçalves JL, Sparovek G. Köppen's climate classification map for Brazil. Meteorol Zeitschrift. 2013 Dec;22(6):711-28.

31. Simepar. Boletim Climático Outono e Inverno/2016 [Internet]. Curitiba/PR; 2016. Available from: http://www.simepar.br/prognozweb/simepar/timeline/boletim_climatologico?page=2

32. Baggiolini M. No Title. Rev Suisse Vitic Arboric Hortic [Internet]. 1995;27(1):17-20. Available from: http://geo.drapn.min-agricultura.pt/agri/archivos/folletos/1368709222_Estados fenológicos da planta de mirtilo.pdf

33. Oliveira PB, Pinto RM, Mota M, Oliveira CM. Chilling effect on three highbush blueberry cultivars. Acta Hortic. 2017 Nov;1180:511-6.

34. Song G, Walworth A. An invaluable transgenic blueberry for studying chilling-induced flowering in woody plants. BMC Plant Biol. 2018 Nov;18:265. Available from: https://doi.org/10.1186/s12870-018-1494-z.

35. Saure MC. Dormancy Release in Deciduous Fruit Trees. In: Horticultural Reviews. Hoboken, NJ, USA: John Wiley \& Sons, Inc.;1985. p. 239-300.

36. Anzanello R, Fialho FB, Santos HP dos. Chilling requirements and dormancy evolution in grapevine buds. Ciência e Agrotecnologia [Internet]. 2018 Aug;42(4):364-71. Available from: http://www.scielo.br/scielo.php?script=sci_arttext\&pid=S1413-70542018000400364\&lng=en\&tlng=en

37. Strik BC. Flowering and fruiting on command in berry crops. Acta Hortic. 2012 Jan;926:197-214.

38. Krewer G, NeSmith DS. Blueberry cultivars for Georgia [Internet]. Tifton, GA; 2006. Available from: http://www.smallfruits.org/assets/documents/crops/blueberries/06bbcvproc_Nov0206.pdf

39. Dennis FG. Problems in standardizing methods for evaluating the chilling requirements for the breaking of dormancy in buds of woody plants. HortScience. 2003 Jun;38(3):347-50.

40. Kaufmann $\mathrm{H}$, Blanke $\mathrm{M}$. Substitution of winter chilling by spring forcing for flowering using sweet cherry as model crop. Sci Hortic. (Amsterdam) [Internet]. 2019 Jan;244:75-81. Available from: https://doi.org/10.1016/j.scienta.2018.09.021

41. Yooyongwech S, Horigane AK, Yoshida M, Yamaguchi M, Sekozawa Y, Sugaya S, et al. Changes in aquaporin gene expression and magnetic resonance imaging of water status in peach tree flower buds during dormancy. Physiol Plant. 2008 Nov;134(3):522-33.

42. Beauvieux R, Wenden B, Dirlewanger E. Bud dormancy in perennial fruit tree species: A pivotal role for oxidative cues. Front Plant Sci. 2018 May;9:657. Available from: https://doi.org/10.3389/fpls.2018.00657

43. Kaufmann $\mathrm{H}$, Blanke $M$. Changes in carbohydrate levels and relative water content (RWC) to distinguish dormancy phases in sweet cherry. J Plant Physiol. 2017 Nov;218:1-5. Available from: https://doi.org/10.1016/j.jplph.2017.07.004

44. Simões F, Hawerroth FJ, Yamamoto RR, Herter FG. Water content and carbohydrate dynamics of pear trees during dormancy in Southern Brazil. Acta Hortic. 2014 Nov;1058:305-12.

45. Gasic K, Preece JE, Karp D. Register of New Fruit and Nut Cultivars List 49. HortScience [Internet]. 2018 Jun;53(6):748-76. Available from: https://journals.ashs.org/view/journals/hortsci/53/6/article-p748.xml

46. Scalzo J, Wright G, Boettiger S. Adaptability of blueberries to lower chill growing regions in Australia. Acta Hortic. 2016 May;1117:45-8.

47. Camargo Alvarez H, Salazar-Gutiérrez M, Zapata D, Keller M, Hoogenboom G. Time-to-event analysis to evaluate dormancy status of single-bud cuttings: An example for grapevines. Plant Methods. 2018 Oct;14:94. Available from: https://doi.org/10.1186/s13007-018-0361-0

2021 by the authors. Submitted for possible open access publication under the terms and conditions of the Creative Commons Attribution (CC BY NC) license (https://creativecommons.org/licenses/by-nc/4.0/). 